\title{
The aging human lens: structure, growth, and physiological behaviour
}

\author{
George Duncan, I Michael Wormstone, Peter D Davies
}

The aging human lens has been the subject of intense research over the past 20 years, for a number of quite disparate reasons. The fact that the incidence of cataract rises exponentially with age after 50 years ${ }^{1}$ provides the driving influence for much of the effort, but the unique accessibility, homogeneity, and basic simplicity of structure of the organ itself makes it a fruitful system for fundamental studies of tissue growth, development, and differentiation..$^{2-4}$

Images of the whole human lens in vivo have been available for detailed analysis since the introduction of the quantitative slit lamp (or Scheimpflug) camera (Fig 1). This has been invaluable in providing an understanding of the changes in shape and optical properties both of the 'normal' and cataractous aging lens. ${ }^{5-7}$ The lens is also accessible as an in vitro system of study through the provision of donor eyes for corneal transplant and general research. Since the lens has no direct blood supply, it survives well both in the globe itself and in organ culture media. ${ }^{8-10}$ Whole cataractous lenses were also once routinely available before the advent of extracapsular cataract extraction (ECCE) with intraocular lens implantation and in the past there have been combined slit lamp and in vitro studies which have correlated changes in light scatter and absorbance with specific alterations in ion and protein levels (Fig 1 and Marcantonio et $a l^{11}$ and Hockwin et $a l^{12}$ ).

The optical homogeneity of the lens is also reflected at the cellular level. The entire organ is composed of cells of surface ectodermal origin. The single monolayer of anterior epithelial cells in the mature lens represents a very static population with little cell division and less cell death occurring. ${ }^{2-413}$ Only cells near the equator divide before elongating to form fully differentiated fibre cells that fill the bulk of the lens. The symmetry of growth of the fibre cells was appreciated by late 18 th century anatomists such as Sir David Brewster ${ }^{14}{ }^{15}$ and the cellular symmetry has an optical correlate as very beautiful birefringence patterns can be obtained from the radially symmetric arrangements of lens fibres (Figs 1 and 2). The symmetry and homogeneity of the patterns are maintained into old age, and only break down when cataract intervenes. This symmetry is maintained throughout the continuing, relatively linear, growth of the lens from the age of 10 to 80 years.

Although the advent of ECCE surgery ${ }^{16}$ has deprived lens researchers of many intact cataractous lenses, it has opened up a further, and potentially just as valuable, field of research into the behaviour of aging lens cells. ${ }^{17}$ This review is, therefore, devoted to recent advances in our knowledge of the changes that occur in the cell biology and physiology of the intact lens and also very recent data that have become available concerning the proliferation of cells within the capsular bag that gives rise to age related differ- ences in the severity and incidence of posterior capsular opacification (PCO).

\section{The intact lens-structural and cell biological aspects}

The human lens continues to grow throughout life and at all decades from 10 to 70 years; the male lens is heavier than its female counterpart. ${ }^{18}$ These age related differences between males and females are interesting because not only do their relative susceptibilities to cataract change with age, but so does their response to physical trauma. Below the age of 50, women have a lower incidence of cataract than men, but above that age the incidence is greater. ${ }^{19}$ This suggests a hormonal influence and recent epidemiological studies show that women undergoing hormone replacement therapy have a reduced incidence of cortical cataract compared with a control cohort of the same age. ${ }^{20}$ There have recently been significant advances in our understanding of the possible mechanisms underlying the hormonal input into cataract. Transforming growth factor (TGF- $\beta$ ), which is present in the aqueous and vitreous humours, ${ }^{21}$ has been shown to induce cataract in organ cultured rat lenses exposed to relatively high concentrations of the factor. ${ }^{22}$ Interestingly, lenses from male rats are more susceptible than those from female rats and, furthermore, the latter receive added protection from TGF- $\beta$ if oestrogen is also present in the medium. ${ }^{23}$ The molecular mechanisms underlying the cataractogenic effect of TGF- $\beta$ are poorly understood, but TGF- $\beta$ is known to induce transdifferentiation of lens cells so that they produce at least two types of foreign protein, smooth muscle actin and collagen types 1 and $3 .^{24}$ Neither of these is synthesised in significant amounts by normal lens cells, but can be detected in certain cataracts ${ }^{25}$ and in cells giving rise to PCO. ${ }^{26}$ The TGF- $\beta$ stimulated production of abnormal intracellular and extracellular proteins disrupts the homogeneous structure of the anterior epithelium and light scattering multilayered cell aggregates are produced. ${ }^{23}$ Interestingly, if TGF- $\beta$ is injected into the vitreous chamber of the rat eye in vivo, then the most pronounced changes occur at the bow region of the lens initiating more typical cortical cataracts. $^{27}$

Not only do male and female lenses differ in their relative sensitivity to TGF- $\beta$, but they also respond differently to mechanical stress. Weale ${ }^{1928}$ carried out a quantitative study of the birefringence of male and female lenses and although the overall pattern is the same (Fig 1) the effect of external stress on the birefringence pattern measured in vitro is different in males and females. Weale measured the greatest stress that could be given before an irreversible change in birefringence occurred and although in both cases the magnitude of the reversible stress declines with age, the rate of decline appears to be steeper with 
female lenses. Furthermore he identified a number of female lenses in which the merest mechanical stress induced irreversible birefringence changes. He concluded that this pointed to a subtle structural difference between male and female lenses. ${ }^{192}$ It has previously been pointed out that the cytoplasm of lens fibres represents a remarkably stable gel-like structure and that calcium has a critical role to play in the maintenance of this stability. ${ }^{29}$ Interestingly, calcium also has a critical role in osteoporosis, which is not only more common in aging women than men, but it is a condition for which hormone replacement therapy also provides a good degree of protection. ${ }^{30}$

Birefringence is an optical property arising from a high degree of order in a structure and it has been shown that $\alpha$ crystallin, the major protein of the lens, is capable of a high degree of packing regularity and short range order at high concentrations. In fact, if this were not the case, then the lens optical density would be predicted to be much higher. ${ }^{31}$ The lens optical density does, indeed, increase with age and the rate of increase is much more apparent after the age of 40 years. The lens also becomes increasingly coloured (yellow) with age and the intrinsic fluorescence also increases. All of these changes tend to degrade the optical properties of the lens. ${ }^{19}$

In cataract the changes in the optical properties of the lens are not generally uniformly distributed. Posterior polar cataracts can involve a very small volume of the lens, but as they lie directly on the visual axis, their effect on vision is great (Fig 1). Cortical cataracts can again involve only small areas of the cortex, while pure nuclear cataracts involve a post-translational change in the nuclear proteins alone while the cortex is quite clear and unaffected (Fig 1).

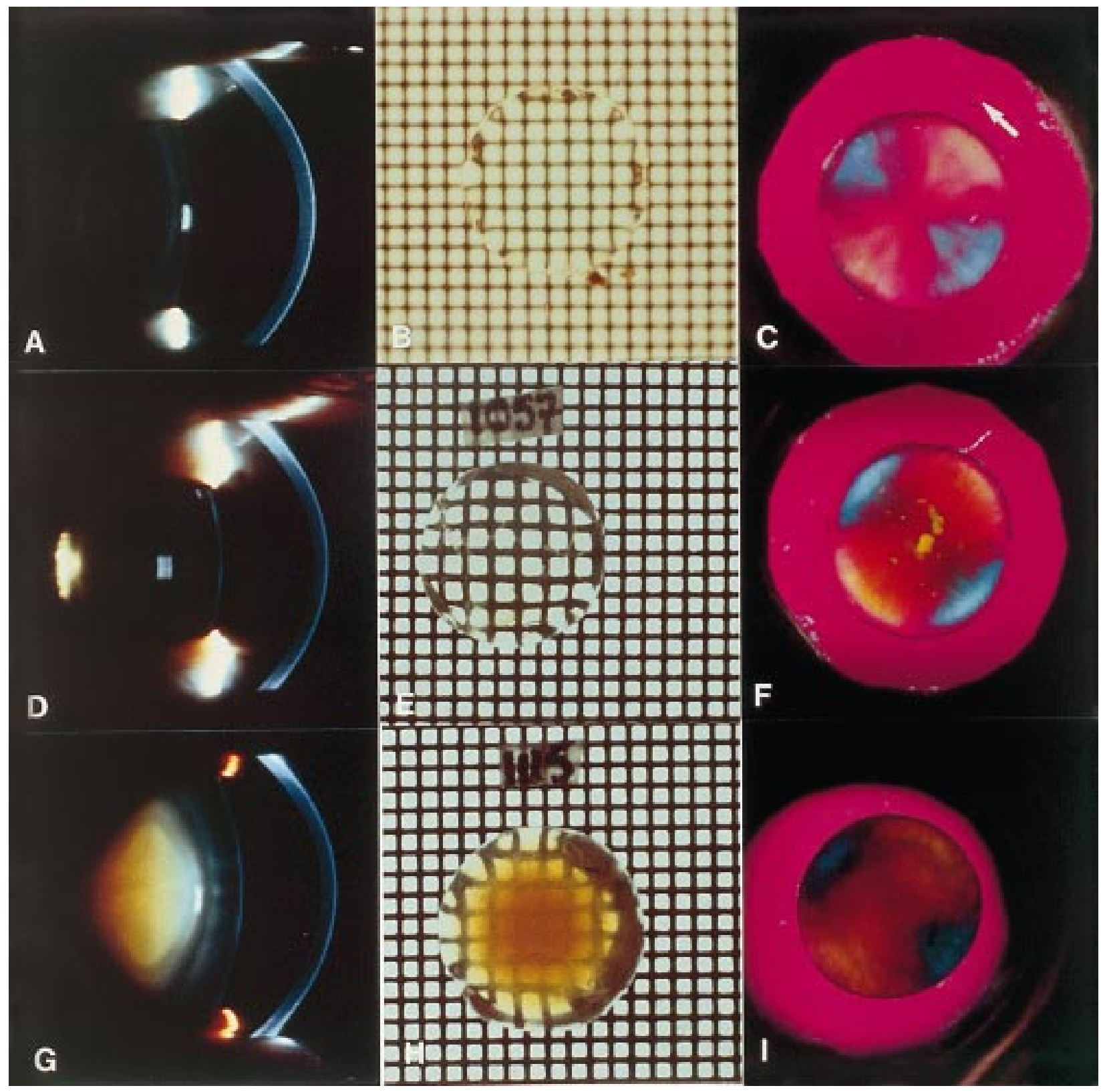

Figure 1 Images of normal human lenses $(A, B$, and $C)$, posterior polar cataract $(D, E, F)$, and pure nuclear cataract $(G, H, I)$. Note that slit lamp camera images $(A, D, G)$ all have a scattering reflect artefact (small white rectangle). The normal subject $(A)$ was 40 years of age and the accompanying in vitro grid photographs $(B)$ and polarising images $(C)$ were obtained from a donor eye of similar age (42 years). The white arrow gives the direction of plane of polarisation of the major axis of the first order red plate. ${ }^{63}$ Note that (B) was photographed under fluid and so the grid is out of focus compared with $(E)$ and $(H)$, which were photographed in air. Also note that the polarising images of the cataractous lenses $(F$ and $I$ ) maintain the bluelyellow radially symmetrical pattern of the normal lens $(C)$ except where the opacities occur in highly localised polar cataract $(F)$ and where the brunescence is strongest in the nuclear cataract $(I)$. The images $(D),(E),(G),(H)$ are taken from Marcantonio et all while the additional images are unpublished. 


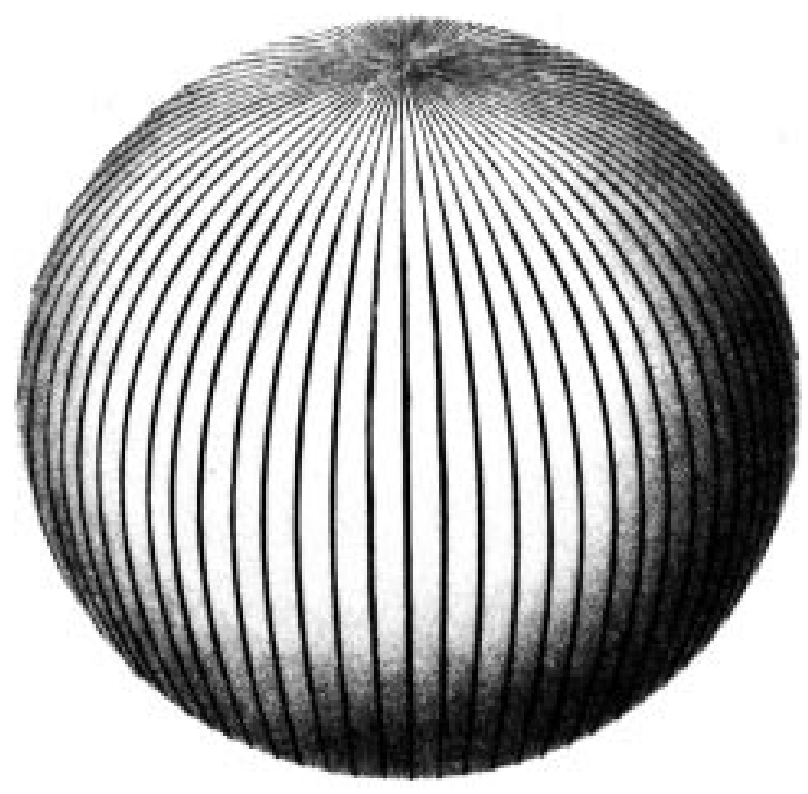

Figure 2 Brewster's model of the arrangement of fibre cells within the lens. ${ }^{15}$ He discovered that the fibre diameter varied throughout the lens and that the tips met in a series of suture lines on the optic axis. Hence, when viewed along the optic axis (as in Fig 1, C, F, and I), such an arrangement would give rise to positive birefringence such that the fibres lying along the direction of the first order red plate give a blue addition colour and those at right angles, a yellow subtraction colour. ${ }^{14}{ }_{1563}$

Recently, attempts have been made to uncover the molecular mechanisms underlying the differences between the different forms of cataract and also the reasons why certain opacities are highly localised.

The smallest opacities are the so called retrodots which are present in normal, non-cataractous lenses and the frequency of their occurrence increases exponentially after 40 years of age. ${ }^{32}$ They appear to be formed from multilayered membrane vesicles and have a surprisingly low protein content, but correspondingly high calcium concentration. ${ }^{33}{ }^{34}$ When there is a larger, but still localised breakdown in lens fibre structure, then the opacities that are formed do disturb the normal visual acuity, especially when they are located on or near the visual axis (see Fig 1). Such lenses have near normal sodium and potassium concentrations but have elevated calcium levels. ${ }^{11}$ Studies employing calcium sensitive microelectrodes to probe the localised opacities and surrounding clear regions have shown that calcium is elevated only in the disrupted areas. ${ }^{35}$ Calcium ions, therefore, appear to have the ability both to disrupt the structure of the lens and also to protect the transparent, unaffected areas by sealing off the damaged fibres. The disrupting properties probably arise through activating the cysteine protease calpain and several proteins of the structurally important lens cytoskeleton appear to be excellent substrates for degradation by the enzyme. ${ }^{36}$ The protecting effect probably arises from two quite different mechanisms. Classically, an increase in cell calcium has long been known to block intercellular communication $^{37}$ and increasing lens cell calcium blocks communication between lens fibre cells. Calmodulin has a major role to play in this process. ${ }^{38}$ Such a calcium induced block would explain why normal fibres can be seen running alongside severely damaged fibres in aging human lenses. ${ }^{39}$ This mechanism would not, however, explain why it is possible for parts of damaged fibre cells to become decoupled from normal sections. ${ }^{39}$ The uncoupling process appears to take the form of a vesiculation whereby fibre membranes from opposite surfaces of the cell appear to be able to fuse. Specific calcium induced vesiculation has been observed to take place both at the ends of broken fibres and in the mid sections of intact, isolated single fibres. ${ }^{40}$ It is possible that calpain also has a role to play in this process by removing space filling cytoskeletal elements what would normally prevent the fibre membranes from collapsing inwards and fusing. ${ }^{3641}$

Pure nuclear cataracts with their brunescent, optically dense nucleus and clear cortex (Fig 1) probably represent a quite different uncoupling mechanism. The oxidative changes that have taken place in the nucleus are not present in the cortex. For example, protein disulphide bridges are formed exclusively in the nucleus and there is an accompanying oxidation of glutathione. The glutathione content of the clear outer cortex is normal and in the reduced form. ${ }^{32}{ }^{42}$ Furthermore, some post-translational modification of the nuclear proteins alone occurs which renders them fluorescent. ${ }^{19}{ }^{42}$ This functional uncoupling and selective oxidation of one region of the lens relative to another does not involve a calcium increase ${ }^{11}$ and does not involve massive structural reorganisation as the birefringence patterns from nuclear cataracts are relatively normal in the clear cortex regions but are obscured in the central regions only by the light absorbing brunescent nucleus (Fig 1).

\section{The intact lens-physiological aspects}

The membrane mechanisms underlying the ionic imbalances of cortical cataracts have been investigated in detail by applying a combination of electrophysiological and radioisotope techniques to lenses that have been removed by intracapsular surgery. ${ }^{43}{ }^{44}$ Since all of the cells within the lens are normally in good electrical communication with one another, the voltage measured by inserting an electrode into the lens is the same at all points throughout the lens. ${ }^{45}$ The membrane mechanisms underlying the ionic imbalances of the cortical cataracts can be investigated by inserting a membrane potential measuring electrode into lenses that have been removed by intracapsular surgery. The membrane potentials of lenses with cortical cataracts measured in this way are extremely low while those of the pure nuclear variety are relatively high and are similar to normal lenses of the same age (Fig 3). The latter statement is important since the membrane potential of the normal lens appears to decline with age, particularly after the age of 40 years. The overall resistance of the membranes to the passage of ions can be determined by inserting a second current passing electrode into the lens. The decline in voltage is accompanied by a decrease in membrane resistance, indicating that some channel mechanism is being activated in the aging lens. ${ }^{45}$ Since the membrane potential is depolarising during this activation, a channel involving an increased movement of sodium must be involved. Although pure sodium channels do appear to reside in lens membranes, ${ }^{46}$ they occur relatively infrequently and a much more likely candidate for the aging activated process is a widely distributed species of non-specific cation channel. This channel is present in lens membranes and appears to permit $\mathrm{Na}^{+}, \mathrm{K}^{+}$, and $\mathrm{Ca}^{2+}$ to pass. ${ }^{47}{ }^{48}$ It is interesting in this respect that the lens sodium and free calcium content also appears to increase after the age of $40 .{ }^{45}$ It is possible to mimic all of the age related membrane permeability and ion content changes in the lens simply by complexing or oxidising membrane sulphydryl groups. ${ }^{49}$ For example, perfusing the isolated lens with very low concentrations of the non-permeating sulphydryl complexing agent PCMPS leads to a very rapid depolarisation of lens membrane potential with a concomitant increase in membrane conductance. These changes are accompanied by an increased influx of sodium and calcium into the lens. ${ }^{49}$ 


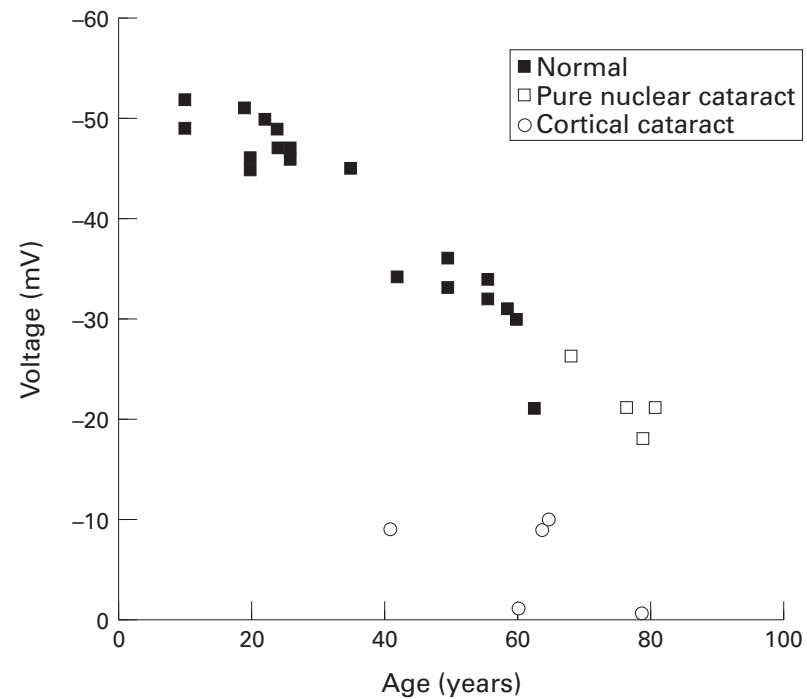

Figure 3 Human lens membrane voltage measured in eye bank and cataract lenses. Note that the pure nuclear cataracts follow the pattern of normal lenses, while the cortical cataracts have voltages considerably lower than normal lenses of a similar age. Data taken from Duncan and Hightower ${ }^{43}$ and Duncan et al. ${ }^{4 .}$

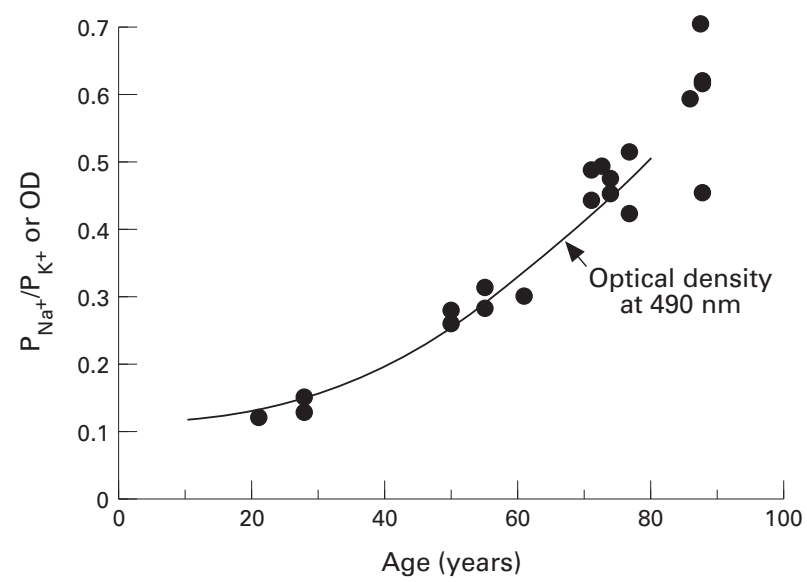

Figure 4 Relative cation permeability $\left(P_{N a} / P_{K}\right)$ of human lenses as a function of age computed from measurements of ion concentration and electrical potential. ${ }^{45}$ The solid line shows the change with age of the mean optical density (OD) of the human lens measured at $490 \mathrm{~nm}^{19}$

The changes that occur in the lens after membrane oxidation are very similar to those that occur in the membranes of rod photoreceptor cells. The cyclic GMP modulated non-specific cation channel in the rod plasma membrane also permits $\mathrm{Na}^{+}, \mathrm{K}^{+}$, and $\mathrm{Ca}^{2+}$ to pass and the effect of membrane oxidation is to cause the channel to spend more time in the open state. ${ }^{50}$ Increasing the open time would, in effect, reduce the overall membrane resistance and depolarise the membrane potential. Although there is no evidence that the oxidative state of the aqueous or vitreous humours changes with age, there is a considerable body of evidence to indicate that the ability of the human lens to withstand oxidative attack in fact declines with age since the overall level of glutathione decreases and the important enzyme glutathione reductase becomes less stable. $^{32}$ Since it is well known that lens nuclear cataract involves protein oxidation ${ }^{42}$ there is now, therefore, the possibility that nuclear and cortical cataracts with their totally different aetiology and morphological appearance may both arise from oxidative mechanisms; one taking place primarily at the surface membranes and the other within the nuclear proteins. This may help explain why the majority of senile cataracts are, in fact, mixed in form, hav- ing contributions from both nuclear and cortical changes. ${ }^{11}$ Recent epidemiological studies of cataract do suggest that a high intake of antioxidants either in the diet, or in the form of supplements, does confer a considerable protective effect. ${ }^{51}$ It is possible to compute for the aging human lens, the expected change in ion permeabilities that would accompany the age related voltage depolarisation and increase in sodium content. ${ }^{45}$ There is a remarkable agreement between the relative increase in permeability to sodium and the increase in lens optical density measured at the wavelength of peak sensitivity of the eye (Fig 4). Both increase more rapidly after the age of 40 and indicate once more a common mechanism between alterations in the ionic and structural protein contents of the human lens.

The above account of the 'resting physiology' of the normal and cataractous lens gives little information concerning the ability of the lens to respond to more natural external stimuli and evidence has accumulated over the past few years that the lens can, indeed, respond to a very wide range of agonists. Again, using electrophysiological methods it is possible to assess how this ability becomes modulated by age. The human lens responds to a surprising range of growth factors and other cytokines including adrenaline, ATP, histamine, and acetylcholine. ${ }^{52}$ The response to the latter is particularly interesting as agents that interfere with acetylcholine metabolism, such as cholinesterase inhibitors, are known to induce cataract. ${ }^{53}$ However, no physiological role for acetylcholine has yet been found in the lens. Electrophysiological experiments on whole human lenses are, however, beginning to shed some light on this intriguing problem since it has recently been found that $\mathrm{ACh}$ induces a marked depolarisation of the membrane potential of the lens. ${ }^{54}$ As the response declines with age, it may first appear that the lens ACh receptors may become less active with age. However, more careful analysis indicates that this is not the case. Thomas et $a l^{54}$ argue that since the lens resting voltage also naturally declines with age (see Fig 3 ) then the extent to which ACh can change or depolarise the lens voltage must also decline with age. In fact, when the ACh induced depolarisation is plotted against resting voltage, then a linear relation is indeed obtained, implying that ACh receptors remain fully functional throughout the life of the lens.

Additional fluorimetric calcium imaging experiments carried out on tissue cultured human lens cells and on the isolated anterior epithelium show that $\mathrm{ACh}$ also stimulates the release of calcium from endoplasmic reticulum stores through the activation of specific muscarinic receptors. ${ }^{55}$ There are many potential sources of ACh in the tissues surrounding the lens, including the ciliary body and retina, and it now appears that increasing ACh in the vicinity of the lens would be expected both to depolarise the lens and increase the free calcium content. ${ }^{545}$ Interestingly, an increase in lens calcium and membrane depolarisation is associated with cortical cataracts (see Fig 3 and Duncan and $\mathrm{Jacob}^{35}$ and Duncan and Hightower ${ }^{43}$ ).

\section{The lens capsular bag-PCO mechanisms and age}

The most common surgical procedure currently performed to treat cataract is extracapsular cataract surgery (ECCE), which consists of lens substance removal and irrigation/aspiration of residual lens fibres. ${ }^{56}$ This procedure leaves the capsular bag in situ and permits an intraocular lens (IOL) to be implanted into this natural holder. However, a proportion of the lens anterior and equatorial epithelial cell population survives the various surgical manipulations. These viable cells do not remain static on the capsule, but proliferate most notably across the previously cell free posterior surface, subsequently 


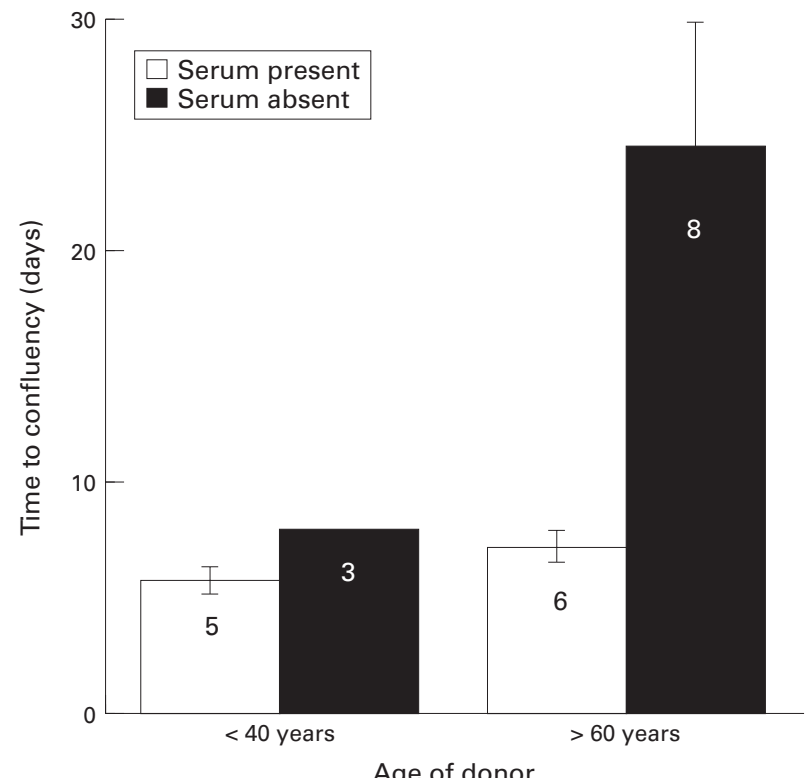

Figure 5 The effects of age and serum on time to confluence of cells on the human posterior capsule. Cell growth was observed using phase contrast microscopy. Confluency was taken at the point when $100 \%$ of the area on the posterior capsule, within the confines of the capsulorhexis, was covered by epithelial cells. Serum data were taken from Liu et al ${ }^{58}$ and serum free data from Wormstone et al. ${ }^{17}$ The numbers of different capsules used to obtain the data are given.

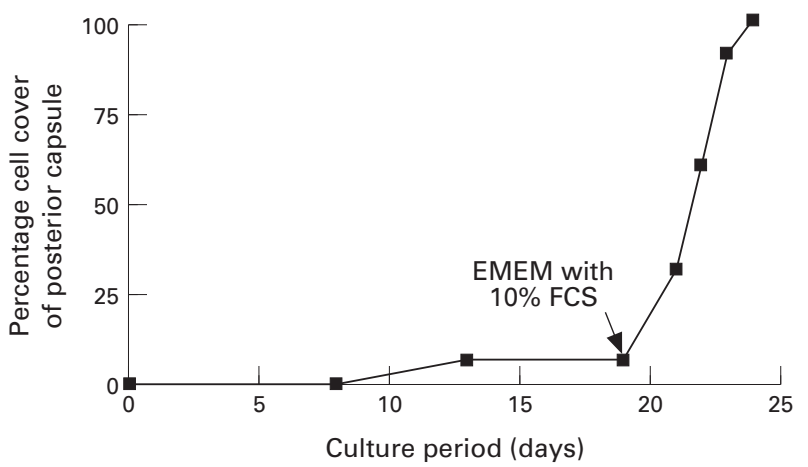

Figure 6 Cell cover on the posterior capsule from a 78-year-old donor lens as a function of time. The capsular bag was initially cultured in protein free medium where it ceased to grow after 12 days. The culture medium was then supplemented with serum after 19 days. The time to confluency $(100 \%)$ was estimated as in Figure 5. Data taken from Wormstone et al. ${ }^{1}$

entering the visual axis. ${ }^{16}$ This aberrant growth gives rise to a secondary visual impairment known as posterior capsule opacification (PCO) or secondary cataract, affecting $20-50 \%$ of patients to the point where further surgery is required. A study by Moissiev et $a l^{57}$ gives an overall PCO incidence, 4 years after ECCE surgery, of $41 \%$ from a pool of 94 patients. In addition, it was shown that patients aged over 40 years were found to have a lower incidence $(37 \%)$ than those under 40 years $(70 \%)$, which clearly demonstrated PCO is inversely related to age. PCO is of particular importance in infantile eyes where it is nearly universal if the posterior capsule is left intact. ${ }^{16}$ As PCO is a major clinical problem a great deal of effort has been directed towards developing both in vivo and in vitro techniques to investigate the mechanisms of PCO. ${ }^{16559}$ However, despite the well established relation between age and PCO, very few experimental investigations have been carried out to understand this phenomenon.

In the normal lens the mitotic index is low and in vitro studies show that the dividing cells are strictly confined to the equatorial region of the epithelium. ${ }^{3410}$ However, once the capsule has been breached and the fibres removed, the mitotic index is dramatically increased..$^{10}$ Interestingly, the increase is first apparent in the equatorial zone rather than at the injured rhexis region. ${ }^{17}$ Within a few days, dividing cells can be detected throughout the anterior epithelium and cells can also be seen moving across the posterior capsule. Modern imaging techniques permit a detailed study of the characteristics of PCO in vivo and it is now apparent that cell growth can also be observed within a few weeks of the operation..$^{59}{ }^{60}$ Growth on the posterior capsule is more rapid and prolific than that on the IOL surface. ${ }^{61}$ This is precisely the pattern seen in vitro when a serum free medium is used to culture the capsular bag. ${ }^{17}$ Other clinical features of PCO are also reproduced in vitro and they include wrinkling and tensioning of the bag and light scattering and multilayering of cells. ${ }^{17}{ }^{58}$ We can be confident, therefore, that the behaviour of cells in vitro faithfully reflect their behaviour in vivo.

Probably the most important finding of the in vitro studies has been the impressive growth of human lens cells in the capsular bag in an entirely growth factor free environment. ${ }^{17}$ This in itself helps to explain why PCO is such a common problem. Growth within capsular bags from younger donors ( $<40$ years) was threefold faster than growth within older capsular bags ( $>60$ years), again reflecting clinical findings. ${ }^{57}$ Interestingly, serum stimulation had little effect on younger cells, but older cells could be driven at rates approaching those of their younger counterparts (Fig 5). This suggests that the difference observed in the absence of serum is due to an age related slowing down in the production of growth factors, rather than a lack of appropriate receptors. Furthermore, some aged capsules showed only partial cover of the posterior capsule and addition of high serum induced a rapid proliferation until confluency was attained (Fig 6). There are reports that $\mathrm{PCO}$ in vivo can be greatly stimulated by inflammatory episodes. ${ }^{62}$

The capsular bag system has shown that lens cells have a great, inherent capacity to proliferate and yet cells within the intact lens divide only slowly and in a very defined region. It will, therefore, be necessary in the future to investigate the factors that limit cell growth in the lens as well as those which stimulate proliferation. Most studies in the past have been limited to investigating the external factors, such as FGF, that might control growth. ${ }^{4}$ The recent data reviewed here suggest that much more attention should be focused on the factors produced by the lens itself both when growth is limited and when it is stimulated. The necessary in vitro systems are now in place for the whole lens ${ }^{9}$ and capsular bag ${ }^{17}$ for these age related studies to proceed apace.

We wish to thank Drs Julia Marcantonio, Julie Sanderson, Steven Bassnett, Christopher Liu, Gregoire Thomas, and also Mrs Pam Keeley for their invaluable contributions to many aspects of this work. We also acknowledge material support from the East Anglian Eye Bank and financial support from The Humane Research Trust and The British Council for the Prevention of Blindness.

GEORGE DUNCAN I MICHAEL WORMSTONE

School of Biological Sciences, University of East Anglia, Norwich NR4 7TJ

PETER D DAVIES

Department of Ophthalmology, West Norwich Hospital, Bowthorpe Road, Norwich

Correspondence to: G Duncan.

1 Kahn HA, Leibowitz HM, Ganley JP. The Framingham Eye Study. 1. Outline and major prevalence. Am f Epidemiol 1977;106:17-326.

2 Duncan G, ed. Mechanisms of cataract formation in the human lens. London: Academic Press, 1981

3 Bloemendal H, ed. Molecular and cellular biology of the eye lens. New York: John Wiley, 1981. 
4 McAvoy JW, Chamberlain CG. Growth factors in the eye. Prog Growth Fact Res 1990;2:29-43.

5 Brown N. The change in shape and internal form of the lens of the eye on accommodation. Exp Eye Res 1973;15:441-60.

6 Brown N, Hungerford J. The influence of the size of the lens in ocular disease. Trans Ophthal Soc UK 1982;102:359-63.

7 Hockwin O, Dragomirescu V, Laser H. Age-related changes in normal and cataractous human lens density obtained by microdensitometric image analysis of Scheimpflug photographs. Graefes Arch Clin Exp Ophthalmol 1982;219:255-62.

8 Piatigorsky J, Fukui HN, Kinoshita JH. Differential metabolism and leakage of protein in an inherited cataract and a normal lens cultured with ouabain. Nature 1978;274:558-62.

9 Marcantonio JM, Duncan G. Amino acid transport and crystallin synthesis in the bovine lens. Exp Eye Res 1983;36:429-40.

10 Rakic J-M, Galand A, Vrensen GFJM. Separation of fibers from the capsule enhances mitotic activity of human lens epithelium. Exp Eye Res 1997;64: 67-72.

11 Marcantonio JM, Duncan G, Davies PD, Bushell AR. Classification of human senile cataracts by unclear colour and sodium content. Exp Eye Res human senile cata

12 Hockwin O, Eckerskorn AJ, Brown NAP. Epidemiological study of the association between lens cataract and case history, blood composition and enzymes involved in lens carbohydrate metabolism. Lens Res 1984;2:23-42.
Harocopos GJ, Kolker AE, Beebe DC. Is apoptosis associated with cataract formation in humans? Invest Ophthalmol Vis Sci 1996;37:S651.

14 Brewster D. On the anatomical and optical structure of the crystalline lenses of animals, particularly that of the cod. Phil Trans Roy Soc Lond 1833;123: 323-32.

15 Duncan G. Brewster's contribution to the study of the lens of the eye: an experimental foundation for modern biophysics. In: Morrison-Low AD, Christie JRR, eds. Martyr of science. Edinburgh: HMSO, 1984;101-3.

16 Apple DJ, Solomon KD, Tetz MR, Assia EI, Holland EY, Legler VF, et al. Posterior capsule opacification. Surv Ophthalmol 1992;37:73-116.

17 Wormstone IM, Liu CSC, Rakic J-M, Marcantonio JM, Vrensen GF, Duncan $\mathrm{G}$, et al. Human lens epithelial cell proliferation in a protein-free medium. Invest Ophthalmol Vis Sci 1997;38:396-404.

18 Harding JJ, Rixon KC, Marriott FHC. Men have heavier lenses than women of the same age. Exp Eye Res 1977;25:651-5.

19 Weale RA. Physical changes due to age and cataract. In: Duncan G, ed. Mechanisms of cataract formation in the human lens. London: Academic Press, 1981:47-70.

20 Cumming RG, Mitchell P. Hormone replacement therapy, reproductive factors and cataract-the Blue Mountains Eye Study. Am $\mathcal{f}$ Epidemiol 1997; 145:242-9.

21 Tripathi R, Borisuth N, Tripathi B. Growth factors in the aqueous humor and their therapeutic implications in glaucoma and anterior segment disorders of the human eye. Drug Dev Res 1991;22:1-23.

22 Hales AM, Chamberlain CG, McAvoy JW. Cataract induction in lenses cultured with transforming growth factor- $\beta$. Invest Ophthalmol Vis Sci 1995;36:1709-13.

23 Hales AM, Chamberlain CG, Murphy CR, McAvoy JW. Estrogen protects lenses against cataract induced by TGF $\beta$. F Exp Med 1997;185:273-80.

24 Hales AM, Schulz MW, Chamberlain CG, McAvoy JW. TGF $\beta_{1}$ induces lens cells to accumulate $\alpha$-smooth muscle actin, a marker for subcapsular cataracts. Curr Eye Res 1994;13:885-90.

25 Schmitt-Graff A, Pau H, Spahr R, Piper HM, Skalli O, Gabbiani G. Appearance of $\alpha$-smooth muscle actin in human eye lens cells of anterior
capsular cataract and in cultured bovine lens-forming cells. Differentiation capsular cataract

26 Frezzotti R, Caporossi A, Mastrangelo D, Hadjistilianou T, Tosi P, Cintorino $\mathrm{M}$, et al. Pathogenesis of posterior capsular opacification II: Histopathological and in vitro culture findings. $\mathcal{F}$ Cataract Refract Surg 1990;16:353-60.

27 Hales AM. Influence of TGF $\beta$ on the rat lens: implications for cataract. $\mathrm{PhD}$ Thesis, University of Sydney.

28 Weale RA. Sex, age and birefringence of the human crystalline lens. Exp Eye Res 1979;29:449-61.

29 Marcantonio JM, Duncan G, Rink H. Calcium-induced opacification and loss of protein in the organ-cultured bovine lens. Exp Eye Res 1986;42:61730 .

30 Griffing GT, Allen SH. Estrogen replacement therapy at menopause. How benefits outweigh risks. Postgrad Med 1994;96:131-40.

31 Delaye M, Tardieu A. Short range order of crystallin protein accounts for eye lens transparency. Nature 1983;302:415-7.

32 Harding JJ, Crabbe MJC. The lens: development proteins, metabolism and cataract. In: Davson $\mathrm{H}$, ed. The eye. 3rd ed. Vol 1b. New York: Academic Press, 1984:207-492.

33 Harding CV, Chylack LT, Susan SR, Lo W-K, Bobrowski WF. Elemental and ultrastructural analysis of specific human lens opacities. Invest Ophthalmol Vis Sci 1982;23:1-13.

34 Vrensen GFJM, Willekens B, De Jong PTVM, Shun-Shin GA, Brown NP, Bron AJ, et al. Heterogeneity in ultrastructure and elemental composition
of perinuclear lens retrodots. Invest Ophthalmol Vis Sci 1994;35:199-206.
35 Duncan G, Jacob TJC. Calcium and the physiology of cataract. In: Nugent $\mathrm{J}$, Whelan J, eds. Human cataract formation. Ciba Found Symp 1988;106:132-48.

36 Truscott RJW, Marcantonio JM, Tomlinson J, Duncan G. Calcium-induced opacification and proteolysis in the intact rat lens. Invest Ophthalmol Vis Sci 1990;31:2405-11.

37 Lowenstein WR. Permeability of membrane junctions. Ann NY Acad Sci 1966;137:441-6.

38 Gandolfi SA, Duncan G, Tomlinson J, Maraini G. Mammalian lens inter-fiber resistance is modulated by calcium and calmodulin. Curr Eye Res 1990;9:533-41.

39 Vrensen G, Willekens B. Classification and prevalence of early senile lens opacities in human donor eyes. In: Hockwin O, Sasaki K, Leske MC, eds. Risk factors for cataract development. Dev Ophthalmol. Basle: Karger 1989;17: 181-7.

40 Bhatnagar A, Ansari NH, Wang L, Khanna P, Wang C, Srivastava SK. Calcium-mediated disintegrative, globulization of isolated ocular lens fibers mimics cataractogenesis. Exp Eye Res 1995;61:303-10.

41 Wang L, Bhatnagar A, Ansari NH, Dhir P, Srivastava SK. Mechanism of calcium-induced disintegrative globulization of rat lens fiber cells. Invest Ophthalmol Vis Sci 1996;37:915-22.

42 Augusteyn RC. Proten modification in cataract: possible oxidative mechanisms. In: Duncan G, ed. Mechanisms of cataract formation in the human lens. London: Academic Press 1981;72-115.

43 Duncan G, Hightower KR. Age-related changes in human lens membrane physiology. In: Courtois Y, Faucheux B, Forette B, Knook DL, Tréton JA, eds. Modern trends in aging research. Colloque INSERM. London, John Libbey Eurotext 1986;147:341-8.

44 Lucas VA, Duncan G, Davies PD. Membrane permeability characteristics of perifused human senile cataractous lenses. Exp Eye Res 1986;42:151-65.

45 Duncan G, Hightower KR, Gandolfi SA, Tomlinson J, Maraini G. Human lens membrane cation permeability increases with age. Invest Ophthalmol Vis Sci 1989;30:1855-9.

46 Rae JL, Rae JS. Whole cell currents from non-cultured human lens epithelium. Invest Ophthalmol Vis Sci 1992;33:2262-8.

47 Jacob TJC, Bangham JA, Duncan G. Characteristics of a cation channel on the apical surface of the frog lens epithelium. Qf Exp Physiol 1985;70:40321.

48 Rae JL, Levis RA. Patch voltage clamp of lens epithelial cells:theory and practice. Mol Physiol 1984;6:115-62.

49 Sanderson J, Duncan G. pCMPS-induced changes in lens membrane permeability and transparency. Invest Ophthalmol Vis Sci 1993;34:2518-25.

50 Donner K, Hemila S, Kalamkarov G, Koskelainen A, Pogozheva I, Rebrik T. Sulphydryl binding reagents increase the conductivity of the light-sensitive channel and inhibit phototransduction in retinal rods. Exp Eye Res 1990;51:97-105.

51 Hankinson SE, Stampfer MJ, Seddon JM, Colditz GA, Rosner B, Speizer $\mathrm{FE}$, et al Nutrient intake and cataract extraction in women: a prospective study. BMF 1992;305:335-9.

52 Duncan G, Williams MR, Riach RA. Calcium, cell signalling and cataract. Prog Ret Eye Res 1994;13:623-52.

53 Shaffer RN, Hethrington J. Anticholinesterase drugs and cataracts. Am $\mathcal{F}$ Ophthalmol 1966;62:613-8.

54 Thomas GR, Williams MR, Sanderson J, Duncan G. The human lens possesses acetylcholine receptors that are functional throughout life. Exp Eye Res 1997;64:849-52.

55 Williams MR, Duncan G, Riach RA, Webb SF. Acetylcholine receptors are coupled to mobilisation of intracellular calcium in cultured human lens cells. Exp Eye Res 1993;57:381-4.

56 Sandford-Smith J. The surgical tratment of cataract:extracapsular cataract extraction. Community Eye Health 1994;17:5-9.

57 Moissiev J, Bantov E, Schochat A, Blumenthol M. Long-term study of the prevalence of capsular opacification following extracepsular cataract. $\mathcal{F}$ Cataract Refract Surg 1989;15:531-3.

58 Liu CSC, Wormstone IM, Duncan G, Marcantonio JM, Webb SF, Davies PD. A study of human lens cell growth in vitro:a model for posterior capsule opacification. Invest Ophthalmol Vis Sci 1996;37:906-14.

59 Shah SM, Spalton DJ, Kerr-Muir MK. Specular microscopy of the anterior intraocular lens surface. Eye 1993;7:707-10.

60 Ursell PG, Pande MV, Spalton DJ. The incidence of posterior capsular opacifiction with PMMA, acrylic and silicone IOLS, 2 year follow-up results. Invest Ophthalmol Vis Sci 1997;38:S19.

61 Ibaraki N, Ohara K, Miyamoto. Membranous outgrowth suggesting lens epithelial cell prolifereation in pseudophakic eyes. Am f Ophthalmol 1995; 119:706-11.

62 Jones NP, McLeod D, Boulton ME Massive proliferation of lens epithelial remnants after Nd-YAG laser capsulotomy. Br f Ophthalmol 1995;79:2613.

63 Duncan G. Physics in the life sciences. Oxford: Blackwell Scientific Publications, 1990 